\title{
Medievalista
}

Online

$14 \mid 2013$

Número 14

\section{Taboos and Penitence: Christian Conversion and Popular Religion in Early Medieval Ireland}

Thesis submitted for the degree of Doctor of Philosophy to the School of History and Archives, College of Arts and Celtic Studies, University College Dublin, November, 2012. Thesis supervised by Dr. Elva Johnston

\section{Elaine Cristine dos Santos Pereira Farrell}

\section{(2) OpenEdition}

12 Journals

\section{Electronic version}

URL: http://journals.openedition.org/medievalista/447

DOI: $10.4000 /$ medievalista.447

ISSN: 1646-740X

Publisher

Instituto de Estudos Medievais - FCSH-UNL

Electronic reference

Elaine Cristine dos Santos Pereira Farrell, «Taboos and Penitence: Christian Conversion and Popular Religion in Early Medieval Ireland », Medievalista [Online], 14 | 2013, Online since 01 July 2013, connection on 22 September 2020. URL : http://journals.openedition.org/medievalista/447 ; DOI https://doi.org/10.4000/medievalista.447

\section{(c) (1) (8)}

Mediavalista está licenciado com uma Licença Creative Commons - Atribuição-NãoComercial 4.0 Internacional. 
Título: Apresentação de Tese/ Thesis Presentation

Taboos and Penitence: Christian Conversion and Popular Religion in Early Medieval Ireland. Thesis submitted for the degree of Doctor of Philosophy to the School of History and Archives, College of Arts and Celtic Studies, University College Dublin, November, 2012. Thesis supervised by Dr. Elva Johnston.

Autor(es): Elaine Cristine dos Santos Pereira Farrell

Enquadramento Institucional: School of History and Archives/ Humanities Institute, University College, Dublin, Ireland

Contacto: elaine.pereira-farrell@ucdconnect.ie

Fonte: Medievalista [Em linha]. №14, (Julho - Dezembro 2013). Dir. José Mattoso.

Lisboa: IEM.

Disponível em: http://www2.fcsh.unl.pt/iem/medievalista/

ISSN: 1646-740X

\section{Apresentação de Tese / Thesis Presentation}

\section{Taboos and Penitence: Christian Conversion and Popular Religion in}

\section{Early Medieval Ireland}

Thesis submitted for the degree of Doctor of Philosophy to the School of History and Archives, College of Arts and Celtic Studies, University College Dublin, November, 2012. Thesis supervised by Dr. Elva Johnston.

Elaine Cristine dos Santos Pereira Farrell 
This is a study of the so-called Irish Penitentials. The documents which compose this documental corpus were either produced in Ireland, or influenced the production of Irish documents, between the sixth and the eighth centuries. The penitential literature most likely originated in Britain, was further developed in Ireland, and spread from those areas to the European continent. The Irish penitentials have been accessed by scholars in support of various research investigations, but quite often in conjunction with later penitential texts produced elsewhere. When these documents are considered for studies specifically about Ireland, usually they are studied in conjunction with, and simply as mere support to other sources. Consequently, there is no recent major work contextualizing them and studying their social and cultural relevance or their impact in Ireland at the time of their production.

This was the primary aim of this research: to place the Irish penitential texts in their context of production. They were, however, compared to other documents produced around the same chronological period where relevant, such as secular law, canon law, hagiography, wisdom text and saga literature, as well as with archaeological evidence where possible. The relevance of this work lies in the fact that penitential literature was both a product and an instrument of a second phase of the Christianization process of the Irish. Christianity was brought to Ireland by missionaries in the fifth century. Nevertheless, Christianization is not simply an event, but a process, and the penitential texts played a role as instruments of pastoral care to further instruct already converted Christians about the ways in which they were meant to behave.

On the other hand, the Christian ways taught in the Irish penitentials were not necessarily 'universal'. Christianity changed and was changed by each and every society with which it had contact. Consequently, this study evidenced that the discourse behind the penitentials reveals confrontations and accommodations between the 'new' ideas introduced to the Irish people and the native norms already established. The penitentials provide the modern scholar with an opportunity to observe an 'Irish popular religion' being shaped through these processes. Therefore, this was the secondary objective of this research: the provision of a study of the composition and consolidation of an 'Irish popular religion' between the sixth and the eighth centuries. The results of this research contribute to an understanding of the meaning and relevance of certain regulations provided in the penitential texts. 
In order to accomplish these aims the dissertation was divided into two volumes. Volume one was divided into two parts. The first, Situating the Problem, is the backbone of this research, composed of three chapters which provide the background for the second part. Part II, Proposing Interpretations, has three other chapters analysing some 'sins'/ 'taboos'/ 'crimes' condemned in the penitential texts. Volume two is composed of an Appendix with 266 analytical tables.

The first chapter introduces the research aims, a literature review, the theoretical framework and key concepts. As this is a research primarily about religion, and as religion is part of culture, this is essensially a work of Cultural History. As such, it was fundamental to consider the historiographic debabe around the concepts of "popular culture' and 'popular religion'. The works of outstanding scholars in the field were considered, such as: Carlo Ginzburd, Roger Chartier, Edward Thompson, Peter Burke, Jacques Le Goff, Jean-Claude Schmitt, Aron Gurevich, J.N Hillgarth, Bernadete Filotas and Karen Jolly. However, it was Karen Jolly's definition of 'popular religion' which was adopted and adapted in this study. According to her, 'popular religion' encompasses the whole of Christiniaty, including both the formal aspects of religion as well as the general religious experience of daily life, shared by all believers, regardless of their social rank or level of literacy. She has argued for a positive interpretation of local Christianities which were amalgamated with local cultures and religiosities. And this is the perspective taken in this research. In this sense, Peter Brown's definition of micro-Christianities was also a sine qua non interpretative tool for understanding early medieval Ireland and the Irish penitentials. As a result, in this research it was evidenced aspects of Christianity which were debated theologically by the Irish and re-shaped to their context. Similarly, native practices were re-shaped according to Christian ideals.

Another concept which proved fundamental to the comprehension of certain 'sins' described in the penitentials was 'taboo'. This is essensially an anthropological concept which has been widely discussed by scholars in various fields of the humanities. Nevertheless, a scholar that is still a major reference in the subject is Mary Douglas. Her definition of 'taboo' as functioning as a form of social control and instrument for the maintenance of the status quo and validating of the authority of the ruling classes, proved applicable to the Irish context, as it can be observed in the penitential texts a symbiosis of the concepts of 'sin', 'taboo' and 'crime'. 
In the second chapter, the manuscript tradition, authorship and date of each penitential text are discussed. The penitential texts selected for this study were 15 in total. Decrees of the Synod of North Britain, Grove of Victory, Excerpts from a Book of David, Preface of Gildas on Penance. These four proto-penitentials are most likely from Britain and date from the sixth century. Their authorship is uncertain. The first three have been associated with Saint David, or Dewi, who died circa 589-601. He became a patron saint of Wales but little is known about his life. The latter have been attributed to Gildas, the well known Church Father that wrote On the Ruin and Conquest of Britain, who died circa 540. These four documents were early on circulating in Ireland and inspired the production of penitentials in Ireland. The Penitential of Finnian, according to most scholars, was written by a British churchman who was active and influential in Ireland in the sixth century. The Penitential of Columbanus was written either around the end of the sixth or the beginning of the seventh century for Columbanus's monasteries in Gaul: Annegray, Luxeil and Fontaines. It was definitely influenced by the Irish peregrine, but scholars debate whether it was wholly written by himself or partially by his disciples. The Paenitentiale Ambrosianum was produced either in Britain or in Ireland prior to the Penitential of Cummean. This latter was most likely written by the influential seventh-century Munster scholar Cummianus Longus. The socalled First Synod of Saint Patrick and Second Synod of Saint Patrick are falsely attributed to the fifth-century missionary Patrick. The earliest date for the former conciliar acta, which contains penitential matter, is sixth-century and the latter most likely dates from the seventh-century. The so-called Irish Canons are in fact five little texts dating from around the seventh-century. The so-called Canons of Adomnán were possibly written by Adomnán or his followers. Adomnán was the ninth abbot of Iona between 679 and 704 and a very influential scholar in the British Isles. The authorship of the Bigotian Penitential is unknown. There is no certainty regarding its origin, as some argue that it is Irish and others that it is continental. Nonetheless there is no evidence to rule out the possibility of an Irish origin. It dates either from the seventh century or eight. All these texts were written in Latin, differently from the Old Irish Penitential and the Old Irish Table of Penitential Commutations, which were written in vernacular language in the eighth century, evidencing the continuity of the tradition of penitential compilation in Ireland and the importance given to the sacrament of penance. 
Furthermore, in this second chapter, the methodology used in the thesis was defined, and its results were presentend and analysed. The methodological approaches addopted for the study of the sources mentioned above were two: firstly, the 'sins' and 'crimes' mentioned in each penitential text were listed and quantified. Then the numbers of mentions of each single topic and their percentages were provided in the Appendix, which is therefore a companion to chapter two. Secondly, these results were explored in the subsequent chapters and contrasted to other sources.

The third chapter situated the Irish penitentials within their contexts of production and considered the ideals behind them; it also identified their intended audiences. In order to understand the ideals behind the penitentials and their contexts, it is imperative to consider the educational and social background of scholars such as Cummianus Longus, Adomnán and Columbanus. The penitential texts were produced by the ecclesiastic elites which were related by blood ties to the secular aristocracy and drank therefore from two different sources: Christian teachings and native knowledge. From the theological point of view, the penitential literature was influenced by the writings of then Fathers of the Church, such as Origen, John Cassian, Augustine, Jerome, Gregory the Great, among others. The influence of conciliar acta, both from the continent and from Ireland, is also evident. However, the mutual influence between the penitentials and Irish secular law tracts is also identifiable, such as Crith Gablach, Uraicecht Becc, Uraicechtna Ríar, Bretha Crólige, Bretha im Gatta, and Cáin Lánamna, among others, which were produced in Irish language between the seventh and eight centuries. For example, the idea of exile is present in both secular and penitential legislation. Certain misdeeds such as incest, parricide and frequent theft were condemened in both, secular and ecclesiastical legislation, and exile was often the punishment or penance prescribed for these offences.

In this third chapter, the audiences of the penitentials were identified. The penitentials were basically written for a Christian audience, for people already converted. In the first instance, they were for the confessors, who would actually read these books themselves and be guided by them in the hearing of confession in order to determine the appropriate penance. This means that the penitentials potentially affected the lives of both the confessors and confessants. There are several studies about penance in the middle ages and the frequency with which people would in fact confess and observe penance is still 
open to debate. Consequently, it has also been difficult to identify who would act as confessor. In the particular case of Ireland, the nomenclatures provided in the penitential texts are helpful in identifying the Irish confessor, at least ideally. In the majority of the Irish penitential canons, the priest is indicated as the confessor and has the power of assigning penances to the confessant according to circumstances. The bishop, although less frequently, is also mentioned as responsible for assigning penances and absolution of penitents, particularly for serious offences committed by members of the clergy. The abbot could often act as a confessor and be responsible for penitents, particularly for the exiled ones. Consequenly, it seems that according to the penitentials, ideally in the Irish context, abbots, bishops and priests, but particularly the latter, were meant to be in charge of confession and penance. This reflects the diversity and flexibility of the Church organization in Ireland. On the other hand, it is much harder to identify the confessants. Many scholars believe that the category of lay people who would, in fact, live under a penitential discipline were the manaig, or ecclesiastic-tenants. Conversely, in the penitential texts themselves there is no evidence for this argument, even though there is in other documents. On the contrary, the Irish penitential compilers attempted to embrace the whole society in their regulations, including the laity as a whole, referring to them in various canons. In fact, the Irish compilers of penitential texts did idealise a pastoral care accessible to all, and a society in which penance was a common practice, although, of course, there were limitations to the actual access to and practice of confession and penance to the majority of the converted population.

In the fourth chapter, the penitential canons regulating sexuality were reviewed and analysed, as this subject is present in almost all the penitential texts selected for this study, and is indeed the most prolific topic in these documents. Included in the thematic of sexuality it was analysed canons regulating: fornication, adultery, continence within marriage, divorce, polygamy, love magic, abortion, incest, 'unnatural' sexual positions, homosexuality, and bestiality. The topic of sexuality is one of the most challenging for the modern scholar's attempt to perceive the Church's and societies' mutual influence in the shaping of an 'Irish popular religion'. It was probably one aspect of Christian teachings which took centuries to fully permeate the daily practices of the people. As sexuality is deeply related to marriage, and marriage crucial for social organization, changes in its organization would have had the potential to destabilise social structures. 
The remarkable interest in the sexual life of the Irish is not a surprise, considering that most of the harsh patristic teachings on marital life and sexual practice seem to have been at odds with Irish culture. Irish marital practice was far removed from the ideal of Augustine and other Church Fathers. As evidenced in the secular law, even after the introduction of Christianity to Ireland, polygamy, concubinage, and divorce were all common practices. Despite this, the penitential writers kept a more conservative and orthodox doctrine regarding sexuality. In fact, the excessive repetition of and insistence on canons about sexuality demonstrate that these infringements were seen as an attack on the Church's norms and authority. Accordingly, through the contrast between the Irish penitentials with other contemporary sources, it was possible to argue that the penitential regulations were in fact not based on imaginative ideas of the clergy, but on real issues and real practices. They are, therefore, extremely valuable to the social historian.

In the fifth chapter interpretations against certain food and drink consumption regulations were proposed and their relevance studied. Various Irish penitential texts regulate against food and drink consumption. One of the most important of them for the understanding of this topic is the so-called Canons of Adomnán, as 19 out of 20 canons are about food and drink consumption, representing $95 \%$ of the total in the document. There were a number of food items that early Irish Christian scholars considered 'impure' and 'taboo'. Most of them were meat types and concerned with blood. Carrion was strictly forbidden and its justification was mainly inspired in the Bible, particularly the Old Testament. But, the Irish did not embrace Biblical regulations into their culture without criticism and adaptation. On the contrary, the prohibitions were adapted to local circumstances in order not to represent a threat to the early Irish social and economic structures. In the Old Testament, the consumption of pork, for example, was forbidden, but it was not in the Irish penitentials. On the other hand, stolen food was forbidden in the penitentials in the same proportion as it was in the secular laws.

Finally, in the sixth chapter, canons about perjury, kingship and the practice of diberg (or brigandage), were examined. All those topics are highly informative about Irish society, culture and religiosity. The secular crime of false swearing in the Christian period became a form of 'sin' which was condemned in the penitentials and the discourse to justity it was Christianized. In the penitentials, it was regulated that Mass 
should be offered only for 'good' kings. To comprehend the penitential concept of 'good' versus 'bad' kingship external evidence from documents such as Críth Gablach, Audacht Morainn, De XII Abusiuis, and Collectio Canonum Hibernensis was crucial. Basically, a 'good' Irish king in the Christian period was the one that, besides keeping his obligations towards his people (túath), meeting all the other qualities valued by native society, and avoiding breaking personal geisi or 'taboos', the king also had to avoid committing 'sins', which were for him new 'taboos', as the infraction of any of these would equally make him an 'unrighteous' and 'bad' ruler, bringing tragedy to himself and his kingdom. As a result, kingship was another Irish institution which was Cristianized. On the other hand, the institution of díberg was not; in fact, as it was also condemned by secular society, it was completely opposed by the Church. Díberg can be defined as a kind of brigandage, engaged in by groups of organised young men who pillaged and committed murder. Scholars have argued that the institution of díberg configured a rite of initiation, which was practiced by males of free birth after the termination of their fosterage, at around fourteen years of age. This would represent their transition between puberty and adulthood, a phase preceding marital life. Apparently these young warriors would live this wild life of warfare and raiding until they reached an adult age, around twenty years of age, when they grew a full beard, inherited, and became married property-owners, enjoying full membership of the túath (small kingdom). So, it is evident that in some cases, such as díberg and sexuality, the Church rejected and condemned the pre-Christian native practices, while in other cases, such as perjury and kingship the Church embraced them, defending native Irish institutions and morals.

The achievement of the proposed aims of this dissertation was possible due to the contribution of a number of works related to the themes and problems this dissertation touches upon, such as conversion, popular religion, penitentials, penance, pastoral cares, social control, and taboo. Nevertheless, a number of questions are still incompletely answered. For instance, the actual functioning of the Christian sacraments in Ireland is still a poorly explored topic, which I intend to further explorer in the future. However, it is to be hoped that this dissertation will illuminate some of these issues. The Irish penitentials are a hugely important source for understanding these contexts. They show us the extent to which the Church was part of society, for instance, in areas such as oath 
taking, as mentioned above. They also show it trying to change society, as in matters of sexuality or of reflecting it, as evidenced by the material on food consumption. Often it was in the process of negotiation, something which seems to be behind its view of kingship. These were not documents mechanically copied one from the other, but a crucial source for the cultural and social history of Ireland.

\section{COMO CITAR ESTE ARTIGO}

\section{Referência electrónica:}

FARRELL, Elaine Cristine dos Santos Pereira - "Apresentação de Tese / Thesis Presentation. Taboos and Penitence: Christian Conversion and Popular Religion in Early Medieval Ireland. Thesis submitted for the degree of Doctor of Philosophy to the School of History and Archives, College of Arts and Celtic Studies, University College Dublin, November, 2012. Thesis supervised by Dr. Elva Johnston”. Medievalista [Em linha]. Nº14, (Julho - Dezembro 2013). [Consultado dd.mm.aaaa]. Disponível em http://www2.fcsh.unl.pt/iem/medievalista/MEDIEVALISTA14/farrell1410.html.

ISSN 1646-740X.

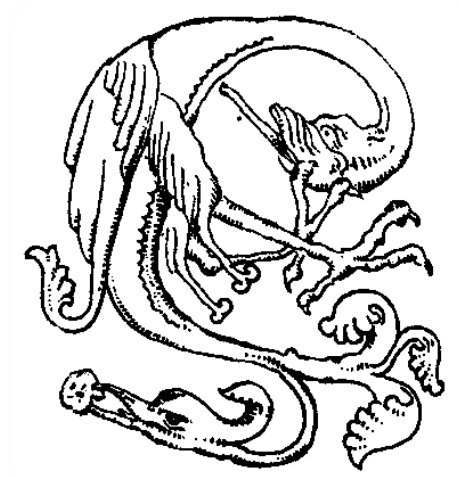

Medievalista online $\mathrm{N}^{0} 14 \mid$ Julho - Dezembro $2013 \odot$ IEM - Instituto de Estudos Medievais 9 www2.fcsh.unl.pt/iem/medievalista 